\title{
POLICY RESEARCH ON IDENTIFYING UPSKILLING NEEDS AND SOCIAL INCLUSION OF MIGRANT SPORTS MANAGERS
}

\author{
Albert Francis Reginald Ramos, Roberto Solinas, \\ Maria Grazia Pirina, \& Paolo Menescardi
}

\begin{abstract}
This study aimed to provide a description of the current needs and perceived focus of 7 countries across different regions in Europe (Bulgaria, Croatia, Cyprus, Italy, Spain, Sweden, and UK) in terms of Sports Management. Different sectors of sport education such as NGO's, Sports Clubs and Associations, Universities, and Vocational and Educational (VET) Providers were identified as the main sources. Inclusion of identifying and evaluating the needs for integration, improvement, and adaptation in the existing curricula of sports coaches and trainers were included on the first phase of data gathering. Second phase data gathering saw a 16-item survey being conducted with 313 respondents $(n=313)$ across the 7 representative countries, aimed at identifying what upskilling needs or points of foci should be prioritized by sports managers for career improvement, subsequent employment, and social inclusion.. Results indicate that 78.7\% of respondents regard formal educational background in sport as essential, and that one of the most important considerations for migrants' upskilling needs to be able to foster an inclusive landscape to educate through sport is having adept communication capacity (15.7\%) and actual management skills (13.08\%). Results were cross analyzed with current and existing policies on sport based on each partner country as well as at the European level. The cross analysis highly suggest that the policies focus on the provisions for skill, education, and qualification matching to address employment and social inclusion mismatches.
\end{abstract}

Key words: Sport Management, Inclusion through Sport

\section{INTRODUCTION}

One of the concerns presently being addressed in the European sports scene is the concept of inclusion across borders in which both players and non-players (such as trainers, coaches, sport managers, etc.), especially those who are migrants from another country face when professing their craft in their respective clubs, associations, academy, NGO's and other sporting organizations. An evidence of this compelling concern is the consistent general unemployment rate. In an online report by Eurostat (November, 2018), the average unemployment rate over the last 10 years from 2007 to 2017 saw a $55 \%$ - $65 \%$ unemployment share for migrants both from outside EU as well as non-native born on reporting member states, with a steady increase until recently. While the overall unemployment rate may be slowly returning to pre-recession levels at $7.1 \%$ as of 2018 (Pew Research Center, 2018), the share of unemployment is climbing at an average of $1 \%$ per year over the second half of the decade for migrants.

With the differences of existing national-level policies of each European country, as well as the dif- ferences in cultures and balancing influences of the socio-civic, state, and economic areas on each countries' take on sport, there is a need to properly identify the ground level concerns and perspectives of migrant sport workers and their attitude towards the existing policies being implemented both on the national as well as the European level. Skill and educational requirements are the usual measurements of capacity and capability to determine the role of sport workers in different organizations.

Currently, the methodology of Education Through Sport (ETS) to bridge the gap of different areas of sports development both in the formal and informal setting in terms of curricular enhancement and capacity building is utilized in one of the collaboration projects of the Erasmus Plus Partnership with MINE VAGANTI NGO and affiliates - the Project curricular Pathways for Migrants' Empowerment through Sport (CPMES).

Education Through Sport (ETS) is an application of non-formal education with the use of sport as a tool to provide a means of lifelong support, livelihood, capacity building, and learning outcomes available 
to the more challenged sectors in society, tailored to the needs of the community in terms of identified sports and related fields of applied disciplines.

\section{METHODS}

This research aimed to determine factors affecting social exclusion of migrants in Europe with the hopes of possibly minimizing the systemic underrepresentation of migrants in sports, and with an effect to indirectly find potential solutions to concerns with regards to migrant unemployment.

Furthermore, this paper aimed to lay-out the needs of upskilling of migrant workers from both perspectives of stakeholders and migrant workers. With first hand data of practices of stakeholders who own sports clubs, organizations, academes, NGO's, and VET providers of how they address hiring of migrants, as well as the perceived needs of migrant workers themselves to further develop their capacity and capability, this study will provide a balance of perspectives and needs from either side of the workforce.

Data was collected in two phases. The first phase of data gathering was a profiling conducted on both stakeholders and migrants with the purpose of identifying initial needs of upskilling. The survey for the stakeholders was a 17-item questionnaire, with the first half seeking characteristics of the organization, and the rest of the survey assessing the focus and programs intended for migrant inclusion and upskilling needs in terms of sports management. The survey for migrants was a 15 -item survey which focused on three parts, the first gathered basic information about the migrants, the second part gathered the communication and digital capacity, and the last part focused on the respondents' personal perception of needs for improvement of professional career related to sports management. Seven consortium partner countries of Bulgaria, Cyprus, Croatia, Spain, Italy, Sweden, and Wales, representing different regions of the European bloc were surveyed, with a total of 359 migrants and 263 stakeholders answering the surveys prepared. The results of this survey paved the way to identify a more specific questionnaire for the second phase
The second phase of the data was a combination of a complementary desk research of the partner countries to provide a landscape of the existing sports policies governing the respective countries as well as in the European level. Researchers laid out the requirements of the existing curricula for sports, with the competencies needed for capacity and capability. A 16-item questionnaire was conducted by consortium partner countries to analyze the combined perceived and required skills needed for migrants in sports management.

The data related to existing policies provided by partner countries were collected to desk research and analyzed through qualitative research method (policy mapping). The common factors and implications of gathered data and policy research wants to provide potential avenues of intervention on a national or European level for upskilling of migrants, more specifically in sports management is then presented as conclusive answers for further implementation by succeeding programs and projects.

By being able to gather a substantial number of migrant sports workers who have first-hand data of what they experience with the sport-related policies of countries, it would be easier to focus on what improvements and foci should be done and implemented by legislators both in a nation-specific and European level needs for employment and social inclusion.

\section{RESULTS}

In the first phase of the survey (Figure 1), the 46\% stakeholders who held sporting organizations preferred specific training should they have migrant workers in their ranks. This is in contrast to the formal education requirement even for higher education or graduate studies as clubs, VET providers, organizations, and the like would rather have migrants trained vocationally, sport specific trained instead of those from formal education in sport. Furthermore, $50 \%$ of stakeholders also emphasized on the need for migrants to be skilled in language and communication (Timon-Andrada, 2019). 


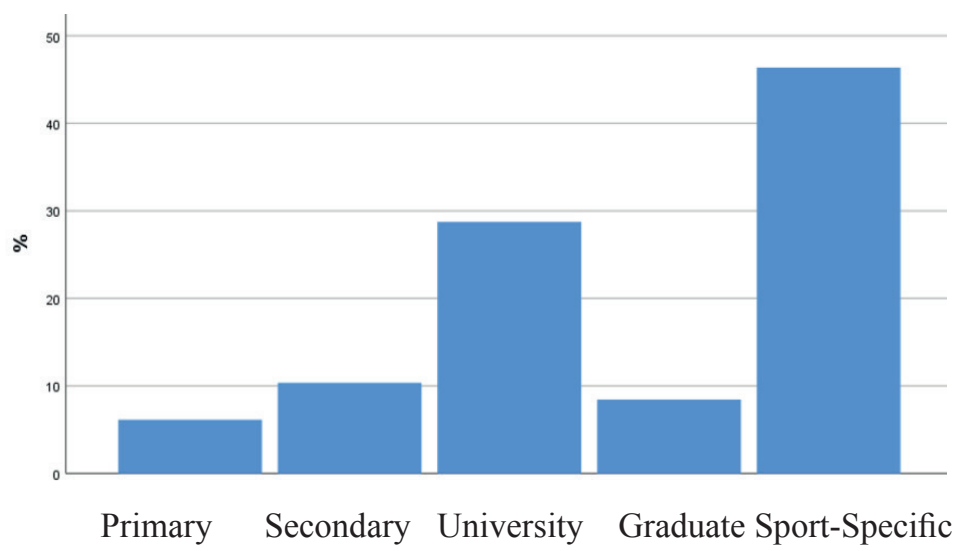

Figure 1. Stakeholder respondents' ideal requirements for migrants in their organization

Among the migrant respondents (Figure 2), only 34\% indicated proficiency in English communica$19.5 \%$ expressed no skills in communicating in En- tion, while 15\% were adept in English communiglish. 31.5\% indicated basic conversational English, cation.

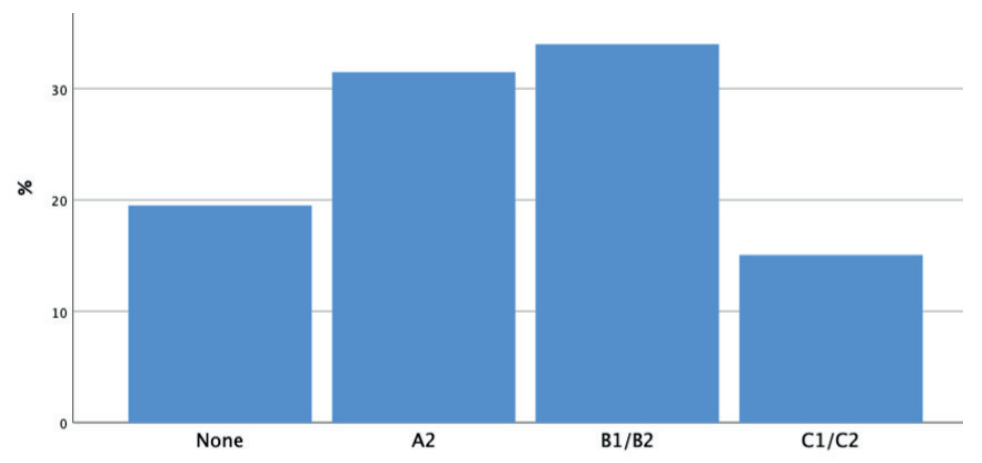

Figure 2. Migrant respondents' English proficiency level

Migrant respondents also showed that around 79\% ganizations, it shows that educational attainment had at least secondary formal education, $3 \%$ of is not a hindrance for employment of migrants but which have attained graduate education (Figure 3). more geared towards the specificity of sport trainWhen compared to the stakeholders' requirement ing. for migrant managers to be employed in their or-

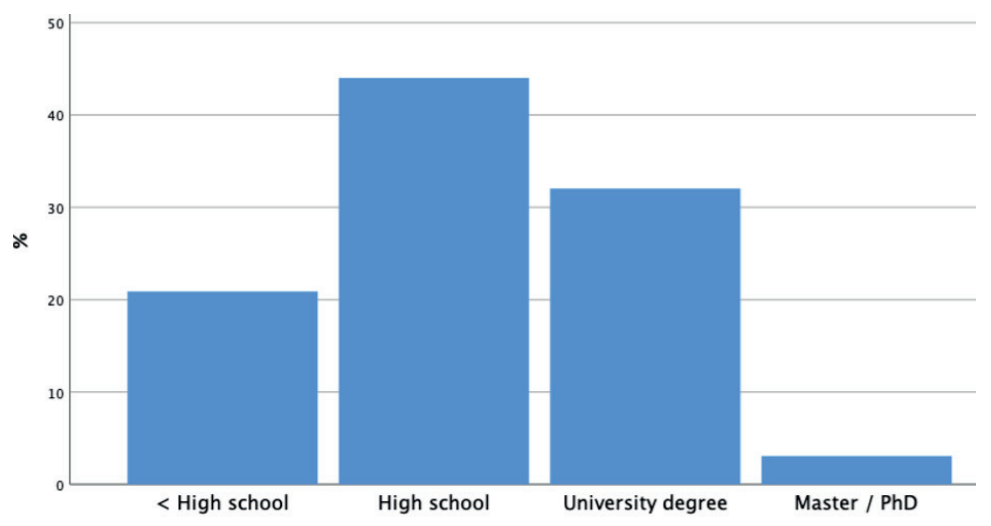

Figure 3. Migrant respondents' educational attainments

Alarmingly, there is a $59.3 \%$ rate of unemployment for the migrant respondents, either as not having a stable means of living or as a volunteer without basic salaries and benefits of a career based job. This is significantly consistent with prevailing European unemployment rates, especially with the youth. 


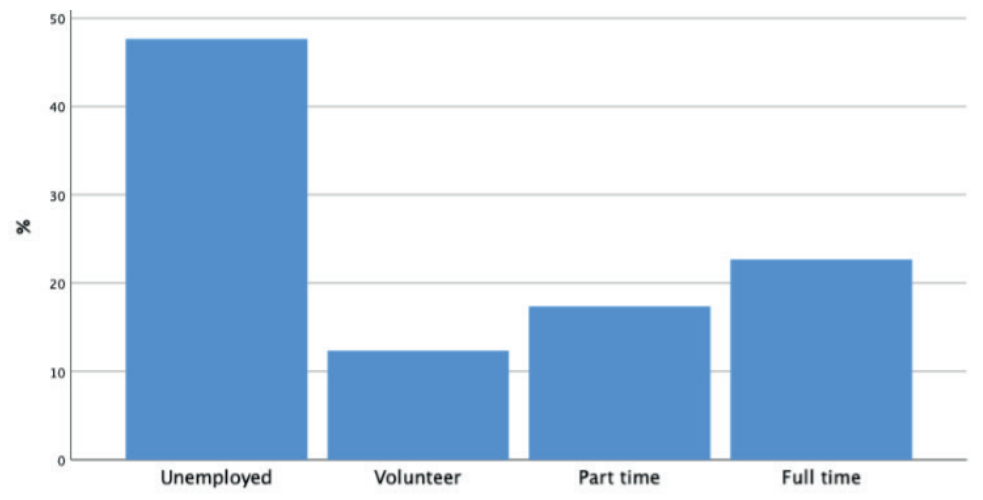

Figure 4. Migrant respondents' employment status

Among the migrant respondents, $42.5 \%$ have indi- trends and needs are similar across EU. This poses a cated that the needs for upskilling and other related significant concern for practically half of the effectrends across Europe is defined per country in con- tive sports policies unique to each country despite trast to the $57.5 \%$ indicating that more or less the having a common sports policy by the EU.

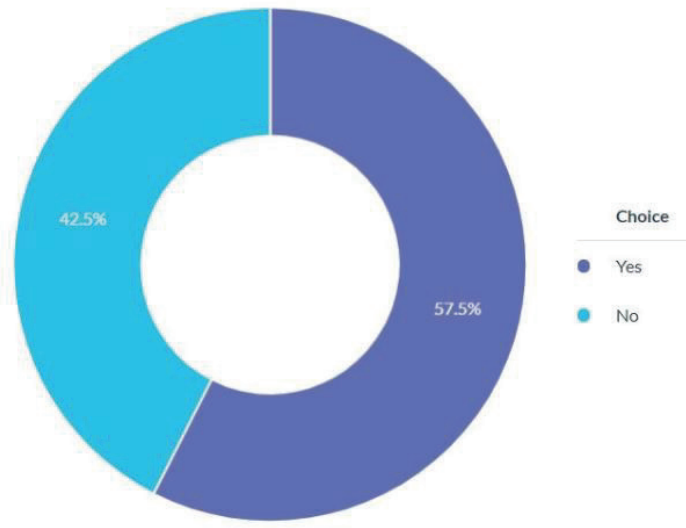

Figure 5. Migrant respondents'view on sports manager needs as the same across Europe

\section{DISCUSSION}

EU Policy for Sport: With the laying of the foundation of the EU policy for sport in the 2007 White Paper, the program for sport was, for the first time provided with a designated budget under the Erasmus+ Programme to focus on the development of Sport and affiliated networks in the European level. With respect to the Treaty of Lisbon in December of 2009, Article 165(1) laid out the policy for sports, indicating that the European Union shall contribute to the promotion and development of European sport issues based on its voluntary nature with the functional purpose in the society and education.

As also indicated in Article 165(2) focusing on the European dimension in sport, the achievement of the policy development would ideally help address the improvement of employability in sport, as well as the promotion of social inclusion across borders. Furthermore, there was an adoption of the Education, Youth, Culture and Sport Council of the EU
Workplan for Sport (2017-2020) which focused heavily on utilizing sport as a means for social inclusion alongside other areas.

As for the desk research on existing paradigms and policies, Table 1 is the summary of gathered policies and current landscapes of the Project Curricular Pathways for Migrants' Empowerment through Sport (CPMES) report by Dochevska (2019). There is the evidence of differing implementations of sports and development of sports management among the partner countries. Some countries have implemented the role of sports managers but have inadequate skills and training. Some countries have undertaken sports management and developed I through a formal education approach. Furthermore, there is a difference in the patronage of the services of sports managers by both recreational and elite sports, not to mention the differences of specific constitutions of sports organizations and clubs for socio-economic reasons. 
Table 1. Desk Research Outcomes of National Policies and Sport Management Paradigms

\begin{tabular}{|c|c|c|c|}
\hline Country & $\begin{array}{c}\text { Policy base: Paradigm } \\
\text { for Sports }\end{array}$ & $\begin{array}{l}\text { Policy base: Function } \\
\text { of Sports Managers }\end{array}$ & $\begin{array}{c}\text { Current landscape: } \\
\text { Main Sports Management } \\
\text { Concerns / Problems }\end{array}$ \\
\hline Bulgaria & $\begin{array}{l}\text { - PE and sport as a social } \\
\text { system } \\
\text { - Patterned to European } \\
\text { Model of Sport } \\
\text { - English Proficiency for } \\
\text { delivery } \\
\end{array}$ & $\begin{array}{l}\text { - The training of a graduate of } \\
\text { the „Sports Management““ } \\
\text { specialty provides profes- } \\
\text { sional realization }\end{array}$ & $\begin{array}{l}\text { - Management of Sport has developed } \\
\text { well over the years; able to carry over } \\
\text { as a new applied science in „Sports } \\
\text { Management“" }\end{array}$ \\
\hline Cyprus & $\begin{array}{l}\text { - Familiarize with sport } \\
\text { management }\end{array}$ & - None gathered & $\begin{array}{l}\text { - Currently, there are } 39 \text { National Sports } \\
\text { Federations registered with the Cyprus } \\
\text { Sports Organization and the Cyprus } \\
\text { National Olympic Committee, and they } \\
\text { are recognized members of the respec- } \\
\text { tive European and International Feder- } \\
\text { ations. (Kartakoullis et al., 2015) }\end{array}$ \\
\hline Croatia & $\begin{array}{l}\text { - Need for sport manage- } \\
\text { ment }\end{array}$ & $\begin{array}{l}\text { - Article } 12 \text { of the Sports Act } \\
\text { in the Republic of Croatia } \\
\text { „,...authorized to perform } \\
\text { mediation activities of ath- } \\
\text { letes from one sports club to } \\
\text { another." }\end{array}$ & $\begin{array}{l}\text { - Employees in Croatian sports organiza- } \\
\text { tions are "mostly managers who come } \\
\text { from politics, economic activities, me- } \\
\text { dia public etc., who are most often not } \\
\text { qualified to conduct sports" (Bartoluci, } \\
\text { Škorić, 2009: 127) }\end{array}$ \\
\hline Italy & $\begin{array}{l}\text { - Collaboration between } \\
\text { public and private Sector } \\
\text { realized }\end{array}$ & $\begin{array}{l}\text { - Needs for managerial com- } \\
\text { petencies for business de- } \\
\text { velopment in sport }\end{array}$ & $\begin{array}{l}\text { - Sports Managers have been getting } \\
\text { more focus and importance not only in } \\
\text { organizations, but also in clubs, associ- } \\
\text { ations, etc. }\end{array}$ \\
\hline Spain & \begin{tabular}{|l|} 
Sport as a socio economic \\
factor for efficiency and \\
economic profitability in \\
different areas
\end{tabular} & \begin{tabular}{|l|} 
- Some regions in Spain re- \\
quire formal education such \\
as Degree in Sports Science \\
for career development in \\
Sports Management
\end{tabular} & $\begin{array}{l}\text { - Has around } 470,000 \text { sports managers } \\
\text { (Gallardo et al, 2018), but there is no } \\
\text { state regulation or framework as a pro- } \\
\text { fession }\end{array}$ \\
\hline Sweden & $\begin{array}{l}\text { - Swedish sports movement } \\
\text { adheres to UN's policies } \\
\text { on Human Rights, Rights } \\
\text { of the Child, and Rights } \\
\text { of Persons with Disabil- } \\
\text { ities } \\
\end{array}$ & $\begin{array}{l}\text { - There is a great need for } \\
\text { competence in sports man- } \\
\text { agement, given the high } \\
\text { level of participation in } \\
\text { sports. This is for the appli- } \\
\text { cation of commercialization } \\
\text { and professionalization } \\
\end{array}$ & $\begin{array}{l}\text { - There is approximately around } 14,000 \\
\text { leisure sports workers in Sweden }\end{array}$ \\
\hline $\begin{array}{l}\text { Wales } \\
\text { (UK) }\end{array}$ & $\begin{array}{l}\text { - Recreational and elite } \\
\text { sport is guided by gov- } \\
\text { ernment intervention } \\
\text { (Sport Wales) }\end{array}$ & $\begin{array}{l}\text { - Sports managers have a } \\
\text { broad spectrum of function } \\
\text { from the grassroot program } \\
\text { to elite level; no indicative } \\
\text { distinction of level }\end{array}$ & $\begin{array}{l}\text { - There is little specific research regarding } \\
\text { sports management; upskilling identifi- } \\
\text { cation for sports managers needs more } \\
\text { focus }\end{array}$ \\
\hline
\end{tabular}

Based on the results of the surveys among stakeholders and migrants, as well as the researched policies governing the countries and the European level, several conclusions may be deduced:

- Education background or attainment is not the main concern for unemployment and social inclusion. It is more of the discrepancy of the expansion of skill requirements and qualifications mismatch.

- While the language barrier is insignificant as a factor in the systemic exclusion of migrants in having a career, it would still be a good focus to further close the gap of employment barriers, considering that the EU has a big migrant, nonnative workforce across different industries.

- There is a need for a focus of alignment or stricter implementation of guidelines and requirements of sports management across EU member states so as to level off the huge discrepancies of unemployment rates based on qualifications mismatch between countries. 
- Trainability is not a concern with migrants, but is actually a welcome prospect for upskilling needs. Furthermore, competency of training and upskilling for sports management positions as a career could be improved.

- The implementation of the EU policy for sport could be further strengthened with a uniform means of adaptation by EU member states, and thus the trickle effect of migrants benefitting from the European level policy implemented would be much easier realized.

\section{REFERENCES}

Bartoluci, M., Škorić, S. (2009). Menadžment u sportu. Zagreb: Odjel za izobrazbu trenera

Društvenog veleučilišta u Zagrebu, Kineziološki fakultet Sveučilišta u Zagrebu.

Dochevska, Y., Djobova, S. (2019). National reports on Research on upskilling needs of Sport Management Educators. Project Curricular Pathways for Migrants' Empowerment through Sport (CPMES). 602975-EPP-12018-1-IT-SPO-SCP.

EU policy in Sport 2007. http://www.europarl.europa. eu/factsheets/en/sheet/143/sport. (Available online as of September 2019)

EU Workplan for Sport. http://data.consilium.europa. eu/doc/document/ST-9639-2017-INIT/en/pdf. (Available Online as of September 2019)

EUROSTAT: Young People - migration and socioeconomic situation. Available online as of September 2019. https://ec.europa.eu/eurostat/statistics-explained/index. php/Young_people_-_migration_and_socioeconomic_situation.
Flores, A., Krogstad, J. M. (2018). EU unemployment rate falls to near pre-recession low. Pew Research Center. https://www.pewresearch.org/fact-tank/2018/07/18/euunemployment-rate-nears-pre-recession-low/. (Available Online as of September 2019)

Gallardo, L., García-Unanue, J., Sánchez-Sánchez, J., Cabello, D., Colino, E., León-Jiménez, M., Felipe, J. L. (2018). New Age of Sport Management Education in Europe Project. Results from Spain. Erasmus + Project. Available from:http://igoid.uclm.es/wp-content/ uploads/2018/04/Subreport-Spain-Data-collection-I-II. pdf.

Kartakoullis, N., Karlis, G., Walker, T., Locke, M. C. (2015). Good Governance and Management Practices: The Perspectives of Cyprus National Sport Federations Administrators, International Journal of Sport Management Recreation \& Tourism, Vol.19, pp.62-74.

Méndez Rial, B. (2014). Evolución de la gestión del deporte en el territorio español: síntesis RETOS. Nuevas Tendencias en Educación Física, Deporte y Recreación, núm. 26, pp. 134-137.

Timon-Andrada, R., Olcina-Camacho, G., Garcia-Calvo, T. (2019). Report on Migrants' Upskilling Needs in Sport. Project Curricular Pathways for Migrants' Empowerment through Sport (CPMES). 602975-EPP-12018-1-IT-SPO-SCP.

\section{Corresponding author:} Albert T. Ramos,

Faculty Dept. of Human Kinetics, University of the Philippines Mindanao, Davao City, 8000 Philippines E-mail: atramos@up.edu.ph, afrtramos@gmail.com 